\title{
Effect of NPK, organic manure and their combination on growth, yield and nutrient uptake of chilli (Capsicum Annum L.)
}

\begin{abstract}
A field experiment was conducted at the research area of department of horticulture, Institute of tropical agriculture and forestry, Hainan University, Haikou, Hainan, China, during the winter season 2016-2017. The research was arranged in randomized complete block design with nine treatments of organic manures in combination with NPK fertilizers having three replications. The highest yield was recorded with T9 treatment $(\mathrm{N}$ : P: K 100:50:50+FYM@8 ton per hectare). Plant height at harvesting, number of branches plant ${ }^{-1}$, number of fruits plant $t^{-1}$, fruit width, fruit length and fruit weight increased significantly with $\mathrm{T}_{9}$ treatment (N: P: K 100:50:50+FYM@8 ton per hectare). Similarly application of NPK100\%+FYM@8 ton per hectare increased oleoresin yield and ascorbic acid content. Application of FYM@8 ton per hectare in combination with NPK100\% increased the uptake of nutrients (N, P, K, Ca, S, and Fe) as compared to control. Similar results were also found in other organic manures along with inorganic fertilizer. The highest net return (Rs. 30183 per hectare) was achieved with the application of NPK100\%+FYM@8 ton per hectare followed by NPK100\%+PM@6 ton per hectare, NPK100\%+VC@10 ton per hectare and NPK100\%+C@7 ton per hectare.
\end{abstract}

Keywords: poultry manure, farm yard manure, vermicompost, compost, ground nut cake
Volume 3 Issue 5 - 2019

\author{
Muhammad Ahsan Altaf,' Rabia Shahid,' \\ Muhammad Asad Altaf,' Ming-Xun Ren,' Ke \\ Tan, ' Wen-Qian Xiang,' Abdul Qadir, ${ }^{3}$ Awais \\ Shakoor, ${ }^{4}$ Muhammad Mohsin Altaf \\ 'Institute of Tropical Agriculture and Forestry, Hainan University, \\ China \\ ${ }^{2}$ Muhammad Nawaz Shareef University of Agriculture Multan, \\ Pakistan \\ ${ }^{3}$ Agricultural Training Institute, Pakistan \\ ${ }^{4}$ School of Resources and Environment, Anhui Agriculture \\ University, China
}

Correspondence: Muhammad Ahsan Altaf, Institute of Tropical Agriculture and Forestry, Hainan University, Haikou, Hainan, China, Email ahsanaltaf88I2@gmail.com

Received: May 17, 2019 | Published: October 02, 2019

\section{Introduction}

Chili (Capsicum annum L.) is an important vegetable crop belongs to Solanaceae family also called Nightshade family. In this family, after tomato and potato, chili is the $3^{\text {rd }}$ most significant crop. In Pakistan, chilies are cultivated on commercial scale, covering the largest area after onion and potato. Economically, chilies are grown as cash crop. The genus capsicum contains almost 20 species and only 5 species are cultivated, out of which Capsicum frutescens and Capsicum annum is regularly cultivated all over the world. ${ }^{1}$ Capsicum frutescence, also called hot peppers, has an extra amount of alkaloid capsaicin $(\mathrm{C} 18 \mathrm{H} 2703)$ which is credible for the pungency. ${ }^{2}$ Lack of increased production skills is considered one of the important causes of minimum yield as well as low quality of chilli. ${ }^{3}$ In Pakistani soils, the organic matter content is getting smaller over time, and this reduction continues by dint of intensive cultivation of crops which are high yielding as these crops eliminate the vital elements from soil. ${ }^{4}$ The balance in addition and reduction of certain vital elements is compulsory for sustainability of a good cropping system. ${ }^{5}$ In agriculture sector, usually imbalanced quantity of chemical fertilizers is used, therefore highest yield could not be attained. Moreover, use of urea as chemical fertilizer by the farmers is being practiced without adding any organic fertilizer which causes hurdle for sustainable agricultural cropping system. ${ }^{6}$

The objective of this study is to determine the effect of different organic manures in combination with NPK fertilizer on plant growth, yield, quality and nutrient uptake. To achieve the objective, experiment was designed using different organic manures in combination with or without inorganic fertilizers. Literature evinces that chilies yield is highly dependent on sufficient supplies of vital nutrient as discussed by. ${ }^{7}$ Presence of organics along with inorganic nutrients is very much essential. It is also revealed in literature that integrated nutrient management with vermicompost, farm yard manures, poultry manures as well as oil cakes have a significant positive impact on chilies yield. ${ }^{8}$

\section{Materials and methods}

\section{Plant material and experimental works}

Experiment was carried out in vegetable research area of Institute of tropical agriculture and forestry, Hainan University, Haikou, Hainan, China, during winter, 2015 and 2016. The Research area is situated in tropical and subtropical climatic region. The present experiment studied the effect of organic manures and NPK fertilizer in chilli (Capsicum Annum L.).

The seeds of sweet pepper cultivar Ghotki were purchased from a seed store in Multan, Punjab, Pakistan. Pepper seeds were sown during winter season in garden trays, filled with nutrient media. Seedlings were ready for transplantation after 5 weeks of seed sowing. Randomized complete block design was used to carry out the experiment with nine treatments and four replications. Each plot area was $6 \times 3$ meter containing 3 rows. There were 9 treatment combinations viz., $\mathrm{T}$, control (without NPK, GC, C, PM, VC and FYM), $\mathrm{T}_{2} \mathrm{~N} 100 \%, \mathrm{~T}_{3} \mathrm{P} 100 \%, \mathrm{~T}_{4} \mathrm{~K} 100 \%, \mathrm{~T}_{5} \mathrm{NPK} 100 \%+\mathrm{GC}$, $\mathrm{T}_{6} \mathrm{NPK} 100 \%+\mathrm{C}, \mathrm{T}_{7} \mathrm{NPK} 100 \%+\mathrm{PM}, \mathrm{T}_{8} \mathrm{NPK} 100 \%+\mathrm{VC}$ and $\mathrm{T}_{9}$; NPK $100 \%+F Y M$. Seedlings of chili were transplanted with $\mathrm{P} \times \mathrm{P} 65$ $\mathrm{cm}$. Source of NPK was Urea, DOP (Di-ammonium Phosphate) and MOP (Muriate of Potash) respectively. NPK were applied at the ratio 100:50:50 respectively in split doses. At the time of transplanting 
half amount of NPK was applied; while the rest of the amount was applied after 50 days of transplantion. Recommended rates of Farm Yard Manure@8 ton per hectare (FYM), Groundnut Cake@5 ton per hectare (GC), Compost@7 ton per hectare (C), Vermicompost@10 ton per hectare (VC) and Poultry Manure@6 ton per hectare (PM) were applied 15 days before transplanting. The soil $\mathrm{pH}$ was 7.7.

Measurement of vegetative parameter: At harvesting stage, plant height and number of branches was counted according to. ${ }^{9}$

Measurement of yield parameter: At harvesting stage, fruits were harvested and the total number and weight in each experimental plot were obtained. All yield parameters such as; fruit yield $\left(\mathrm{kg} \mathrm{ha}^{-1}\right)$, number of fruits plant ${ }^{-1}$, fruit width, fruit length and fruit weight were recorded according to. ${ }^{10}$

Measurements of nutritional parameter: chemical analysis was carried out on plant samples which were collected at harvest stage. Following methods were used for determining N, P, K content in plant samples, micro-kjeldahls method for determining N, vanadomolybdate phosphoric yellow color method for the determination of phosphorus, whereas potassium content was determined by using flame photometric method. ${ }^{11}$ While micronutrients $\mathrm{Ca}, \mathrm{S}$ and Fe were determined by using atomic absorption spectrophotometer. ${ }^{12}$

\section{Measurement of quality parameter}

Oleoresin yield: Oleoresin yield hectare ${ }^{-1}$ was found by applying the following formula, whereas, oleoresin yield was estimated in $\mathrm{Kg} \mathrm{ha}^{-1}$.

Oleoresin yield $=$ fruit yield $-($ discolored fruit $\times$ percent oleoresin in fruit)/100

Ascorbic Acid: It was estimated according to. ${ }^{13}$ Ascorbic acid was measured in $\mathrm{mg} / 100 \mathrm{~g}$ of fruits.

Discolored fruits weight: The discolored fruits were harvested from each unit and discolored fruit weight hectare ${ }^{-1}$ was estimated.

Statistical analysis: XLSTAT (2018) Microsoft office program was used for statistical analysis, and means were compared by LSD method according to Student-Newman Keuls Test.

Economic analysis: The net return $\mathrm{ha}^{-1}$ was found by subtraction of cost of cultivation from gross return. All values were estimated in Rs $\mathrm{ha}^{-1}$.

\section{Net return $=$ Gross return-Cost of Cultivation}

Benefit: Cost Ratio $=$ Gross return/Cost of Cultivation

\section{Results}

Plant height, number of fruits plant ${ }^{-1}$, branches plant ${ }^{-1}$, and fruit weight, length and width are presented in Table 1, and fruit yield hectare $^{-1}$ is shown in Table 2. The application of NPK in combination with FYM recorded maximum plant height at harvesting $(64.51 \mathrm{~cm})$ which was found significantly different from control treatment $(36.55$ $\mathrm{cm})$. The higher number of branches (23.60) was noted in chili with application of NPK $100 \%+F Y M$. The number of fruit plant $^{-1}$, fruit width, fruit length, and fruit weight were statistically maximum with the application of NPK100\%+FYM $(24.56,6.91 \mathrm{~cm}, 4.88 \mathrm{~cm}$ and $69.34 \mathrm{~g} /$ hill respectively) as compared to control treatment (without NPK, GC, C, PM, VC and FYM) (Table 1). However, rest of the applications was similar to each other. The discolored fruit weight was significantly maximum in $T_{1}$ control. Rest of the applications was statistically similar (Table 1). The application of major nutrients (NPK) in combination with FYM obtained greater chili fruit yield as compared to treatment $\mathrm{T}_{1}$ (control) $(951.54 \mathrm{~kg}$ and $598.22 \mathrm{~kg}$ per hectare respectively). But it was similar with NPK100\%+VC, NPK $100 \%+$ PM, NPK $100 \%+C$, NPK $100 \%+$ GC $(843.89 \mathrm{~kg}, 840.54 \mathrm{~kg}$, $841.22 \mathrm{~kg}$ and $803.51 \mathrm{~kg}$ per hectare respectively) (Table 2).

Results exposed that yield of chili $\left(\mathrm{kg} \mathrm{ha}^{-1}\right)$ was observed maximum in treatment $\mathrm{T}_{9}(\mathrm{NPK} 100 \%+\mathrm{FYM})$ as compared to treatment $\mathrm{T}_{1 \text { (Control) }}$, but the treatments $\mathrm{T}_{8}(\mathrm{NPK} 100 \%+\mathrm{VC}), \mathrm{T}_{6}$ $(\mathrm{NPK} 100 \%+\mathrm{C}), \mathrm{T}_{7}(\mathrm{NPK} 100 \%+\mathrm{PM})$ and $\mathrm{T}_{5}(\mathrm{NPK} 100 \%+\mathrm{GC})$ were statistically at par (Figure 1). The treatment $\mathrm{T}_{9}(\mathrm{NPK} 100 \%+\mathrm{FYM})$ obtained significantly maximum oleoresin yield as compared to treatment $\mathrm{T}_{8}(\mathrm{NPK} 100 \%+\mathrm{VC}), \mathrm{T}_{7}(\mathrm{NPK} 100 \%+\mathrm{PM})$. But the treatment $\mathrm{T}_{5}(\mathrm{NPK} 100 \%+\mathrm{GC})$ and $\mathrm{T}_{6}(\mathrm{NPK} 100 \%+\mathrm{C})$, were statistically similar. The applied treatment $\mathrm{T}_{1}$ (control) verified significantly minimum oleoresin yield as compared to other treatments (Figure 2). The ascorbic acid content increased in all treatments along with major nutrients (NPK) in combination with groundnut cake, compost, poultry manure, vermicompost and farm yard manure as compared to treatment $\mathrm{T}_{1}$ (control) (Figure 3).

The nutrient uptake of NPK was found significantly maximum in all treatments as compared to control. The uptake of NPK was notably maximum in treatment $\mathrm{T}_{9}(\mathrm{NPK} 100 \%+\mathrm{FYM})$ (Figure $4 \mathrm{~A}-$ 4C). The nutrient uptake of calcium and sulpher was also statistically higher in all treatments when compare with control. The nutrient sulphur and calcium uptake was recorded maximum in treatment $\mathrm{T}_{9}(\mathrm{NPK} 100 \%+\mathrm{FYM})$ (Figure 5A \& 5B). The rest of the treatments were statistically similar. The uptake of iron was obtained maximum in treatment $\mathrm{T}_{9}(\mathrm{NPK} 100 \%+\mathrm{FYM})$ and minimum uptake of iron was recorded in treatment $\mathrm{T}_{1}$ control (Figure $5 \mathrm{C}$ ).

In the current studies, the economic analysis of all treatments evinced huge change in gross return hectare ${ }^{-1}$. The highest gross return (Rs. 47908 ha $^{-1}$ ) was recorded with treatment NPK100\%+FYM followed by treatment NPK100\%+VC (Rs. $43886 \mathrm{ha}^{-1}$ ) and NPK $100 \%+C$, (Rs. 43780 ha $^{-1}$ ). The minimum gross return (Rs. $33950 \mathrm{ha}^{-1}$ ) was observed without application of organic manures and NPK fertilizer (Table 2) (Figure 6). Consequently, the highest net return was obtained with application of NPK100\%+FYM (Rs. 30183 $\mathrm{ha}^{-1}$ ) followed by application of NPK100\%+PM, NPK100\%+VC and NPK $100 \%+$ C (Rs. 27224, Rs. 27011, Rs. 25705 per hectare respectively), as compared to control treatment (Rs. $18772 \mathrm{ha}^{-1}$ ). B: C ratio was recorded (2.70) maximum with application NPK100\%+FYM as compared to control. The fruit yield was recorded maximum with combined application of farm yard manure along with NPK application and minimum cost was investigated on N100\% compared to NPK $100 \%+F Y M$ (Table 2) (Figure 6).

\section{Discussion}

The current study focused on the effect of organic manures and NPK fertilizer on growth, yield, nutrient uptake and quality of chilli. Growth, yield and quality parameters showed significant increase with the application of organic manures along with NPK fertilizer.

Current study reveals that organic manures coupled with NPK fertilizer have noticeable effects on chilli yield (Table 2) (Figure 1). Outcomes clearly give evidence that application of NPK100\%+FYM obtained significantly maximum chilli yield as compared to other treatments. However, NPK100\%+VC, NPK100\%+C, NPK100\%+PM 
and NPK $100 \%+\mathrm{GC}$ also on par with NPK100\%+FYM (Table 2) (Figure 1). These results are in line with. ${ }^{14-17}$ [18] reported an increase in yield by application of organic manures coupled with NPK fertilizer. The growth and yield parameters, plant height, number of branches plant ${ }^{-1}$, number of fruits plants ${ }^{-1}$, fruit length, fruit width and fruit weight hill-1 were significantly higher with the application of NPK $100 \%$ coupled with FYM (Table 1). The results are related to the findings of. ${ }^{14,19,20}$

The oleoresin yield of chili also significantly increased with the application of organic manures (Figure 2). The increased oleoresin yield may be because of decreased discolored fruit weight and increased yield per unit area. A significant increase in ascorbic acid content was noted with the application of organic manures (Figure 3). The ascorbic acid content statistically increased with the application of NPK $100 \%+F Y M$ as compared to control. These findings are in line with. ${ }^{14,19}$ also stated that combine application of organic manures and
NPK fertilizer increase quality parameter such as ascorbic acid and oleoresin yield, these results are in line with. ${ }^{19,20}$ Further, the statistical increase in the weight of discolored fruits was observed when chilli crop was subjected to $100 \%$ NPK fertilizers in combination with organics manures; these results are in line with. ${ }^{14,19,20}$

The yield potential of chilli is greatly determined by nutrient uptake. The nutrient uptake of $\mathrm{N}, \mathrm{P}, \mathrm{K}, \mathrm{Ca}, \mathrm{S}$ as well as $\mathrm{Fe}$ was increased by applying NPK $100 \%+F Y M$ in comparison to control (Figure 4A-4C \& Figure 5A-5C). The above results were similar with. ${ }^{20,14}$ The increased calcium, sulpher and iron uptake was recorded with combined application of organic and inorganic fertilizers. Similar results were reported by. ${ }^{19}$ [14] described that the improvement in vegetative growth may be due to improved nutrient uptake, especially when NPK is applied with organic fertilizers. Similar results were also described by. ${ }^{17,20}$

Table I Effect of different organic manures and NPK fertilizer on growth and yield attributes

\begin{tabular}{|c|c|c|c|c|c|c|c|}
\hline Treatments & $\begin{array}{l}\text { Plant Height } \\
\text { at harvesting } \\
\text { (cm) }\end{array}$ & $\begin{array}{l}\text { Number of } \\
\text { branches } \\
\text { plant-I }\end{array}$ & $\begin{array}{l}\text { Number of } \\
\text { fruits plant-I }\end{array}$ & $\begin{array}{l}\text { Fruit } \\
\text { length } \\
\text { (cm) }\end{array}$ & $\begin{array}{l}\text { Fruit } \\
\text { width } \\
\text { (cm) }\end{array}$ & $\begin{array}{l}\text { Fruit } \\
\text { weight ( } g / \\
\text { hill) }\end{array}$ & $\begin{array}{l}\text { Weight of } \\
\text { discolored fruits } \\
\text { (kg ha-I) }\end{array}$ \\
\hline TI Control & 36.55 & 11.55 & 10.21 & 3.91 & 2.78 & 41.54 & 111.01 \\
\hline T2 NI00\% & 45.43 & 16.23 & 15.76 & 5.01 & 3.32 & 48.76 & 101.03 \\
\hline T3 PI00\% & 51.24 & 17.73 & 18.44 & 5.43 & 3.98 & 54.23 & 98.96 \\
\hline T4 K $100 \%$ & 48.66 & 18.27 & 16.98 & 5.78 & 3.78 & 52.71 & 103 \\
\hline $\begin{array}{l}\text { T5 } \\
\text { NPK } 100 \%+G C\end{array}$ & 56.56 & 19.2 & 17.12 & 4.98 & 3.56 & 50.59 & 97 \\
\hline T6 NPK I $00 \%+C$ & 61.91 & 20.47 & 21.44 & 6.21 & 3.98 & 59.89 & 93.5 \\
\hline $\begin{array}{l}\text { T7 } \\
\text { NPK } 100 \%+P M\end{array}$ & 59.77 & $|8.5|$ & 19.22 & 6.46 & 4.05 & 64.11 & 95 \\
\hline $\begin{array}{l}\text { T8 } \\
\text { NPK } 100 \%+V C\end{array}$ & 63.21 & 17.2 & 22.43 & 6.5 & 4.07 & 62.45 & 99 \\
\hline $\begin{array}{l}\text { T9 } \\
\text { NPKI } 00 \%+F Y M\end{array}$ & 64.51 & 23.6 & 24.56 & 6.91 & 4.88 & 69.34 & 94.83 \\
\hline LSD $(0.05)$ & 3.11 & 2.38 & 1.08 & 0.51 & 0.46 & 6.39 & 7.51 \\
\hline
\end{tabular}

T,Treatments; Represented data mean of four replication and significant $(\mathrm{P}<0.05)$ difference according to Student-Newman Keuls Test.

Table 2 Economic analysis of chilli as influenced by various organic manures and NPK fertilizer

\begin{tabular}{|c|c|c|c|c|c|}
\hline Treatments & Fruit Yield (kg ha-I) & Gross return (Rs.ha-I) & $\begin{array}{l}\text { Net } \\
\text { return }\end{array}$ & Cost of Cultivation & B:C Ratio \\
\hline TI Control & 1008.85 & 33950 & 18772 & 15178 & 2.24 \\
\hline T2 NI00\% & 1201.29 & 39062 & 23837 & 12225 & 2.57 \\
\hline T3 PI00\% & 1255.04 & 35495 & 20609 & 14886 & 2.38 \\
\hline $\mathrm{T} 4 \mathrm{KI} 100 \%$ & 1308.46 & 40871 & 24296 & 16575 & 2.47 \\
\hline T5 NPKI00\%+GC & $|403.5|$ & 38269 & 22894 & 15375 & 2.49 \\
\hline T6 NPKI00\%+C & 1432.22 & 43780 & 25705 & 18075 & 2.42 \\
\hline T7 NPK I00\%+PM & 1440.54 & 43749 & 27224 & 16525 & 2.65 \\
\hline T8 NPK I00\%+VC & 1443.89 & 43886 & 27011 & 16875 & 2.6 \\
\hline T9 NPK I00\%+FYM & 1551.94 & 47908 & 30183 & 17725 & 2.7 \\
\hline LSD (0.05) & $119.6 \mid$ & 41.51 & 2989 & --- & 0.21 \\
\hline
\end{tabular}

T, Treatments; Represented data mean of four replication and significant $(P<0.05)$ difference according to Student-Newman Keuls Test. 


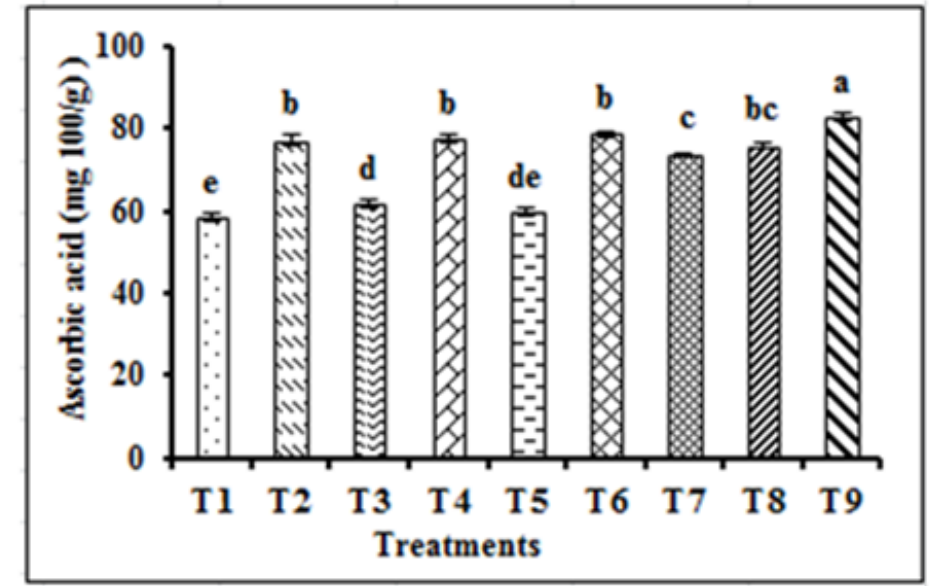

Figure I Chili yield affected by organic manures and NPK Fertilizer.Treatments,T; (TI; without NPK, GC, C, PM,VC and FYM- control,T2; NI00\%,T3; PI00\%, T4; K I00\%, T5; NPK+GC, T6; NPK+C, T7; NPK+PM, T8; NPK+VC, T9; NPK+FYM). Error bar indicate mean of 4 replication $\pm S E$. Different letters indicate significant difference determined by Student-Newman-Keuls test at $\mathrm{P}<0.05$.

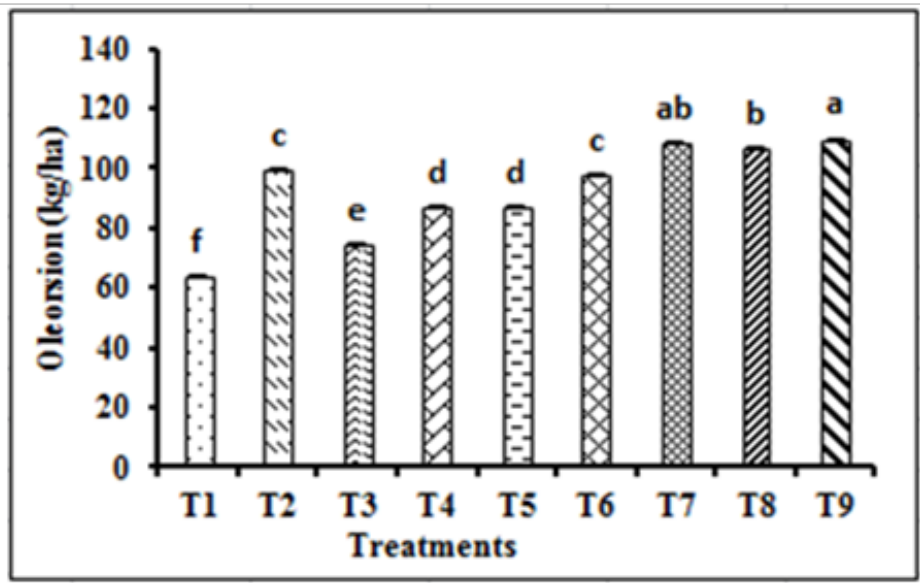

Figure 2 Oleoresin yield of chili as affected by organic manures and NPK Fertilizer. Treatments=T, (TI; without NPK, GC, C, PM, VC and FYM- control, T2; NI00\%, T3; PI00\%, T4; KI00\%, T5; NPK+GC, T6; NPK+C, T7; NPK+PM, T8; NPK+VC, T9; NPK+FYM). Error bar indicate mean of 4 replication \pm SE. Different letters indicate significant difference determined by Student-Newman-Keuls test at $\mathrm{P}<0.05$.

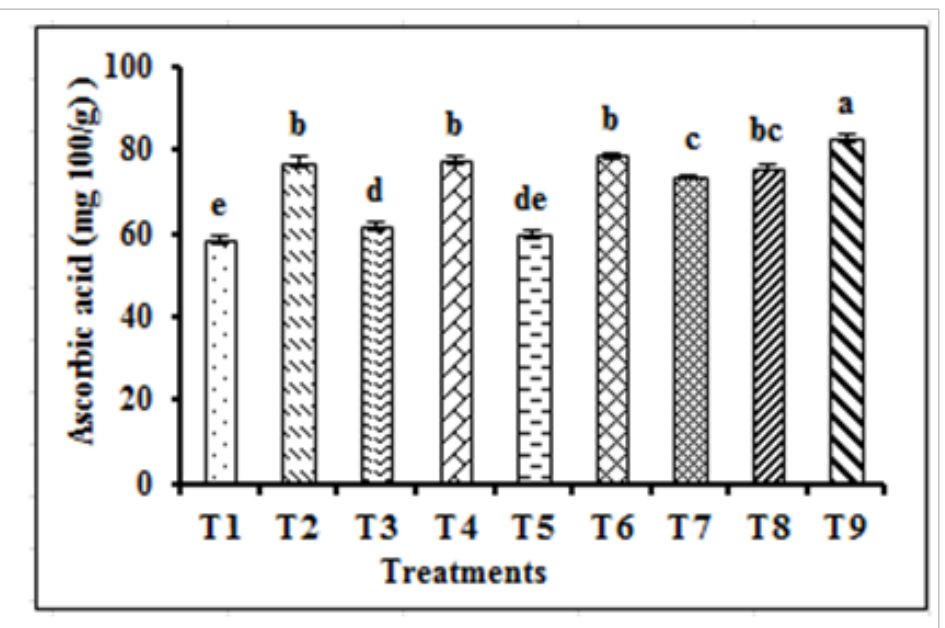

Figure 3 Ascorbic acid content of chili as affected by organic manures and NPK Fertilizer. Treatments=T; (TI; without NPK, GC, C, PM,VC and FYM- control, T2; NI 00\%, T3; PI00\%, T4; KI00\%, T5; NPK+GC, T6; NPK+C,T7; NPK+PM,T8; NPK+VC,T9; NPK+FYM). Error bar indicate mean of 4 replication \pm SE. Different letters indicate significant difference determined by Student-Newman-Keuls test at $\mathrm{P}<0.05$. 

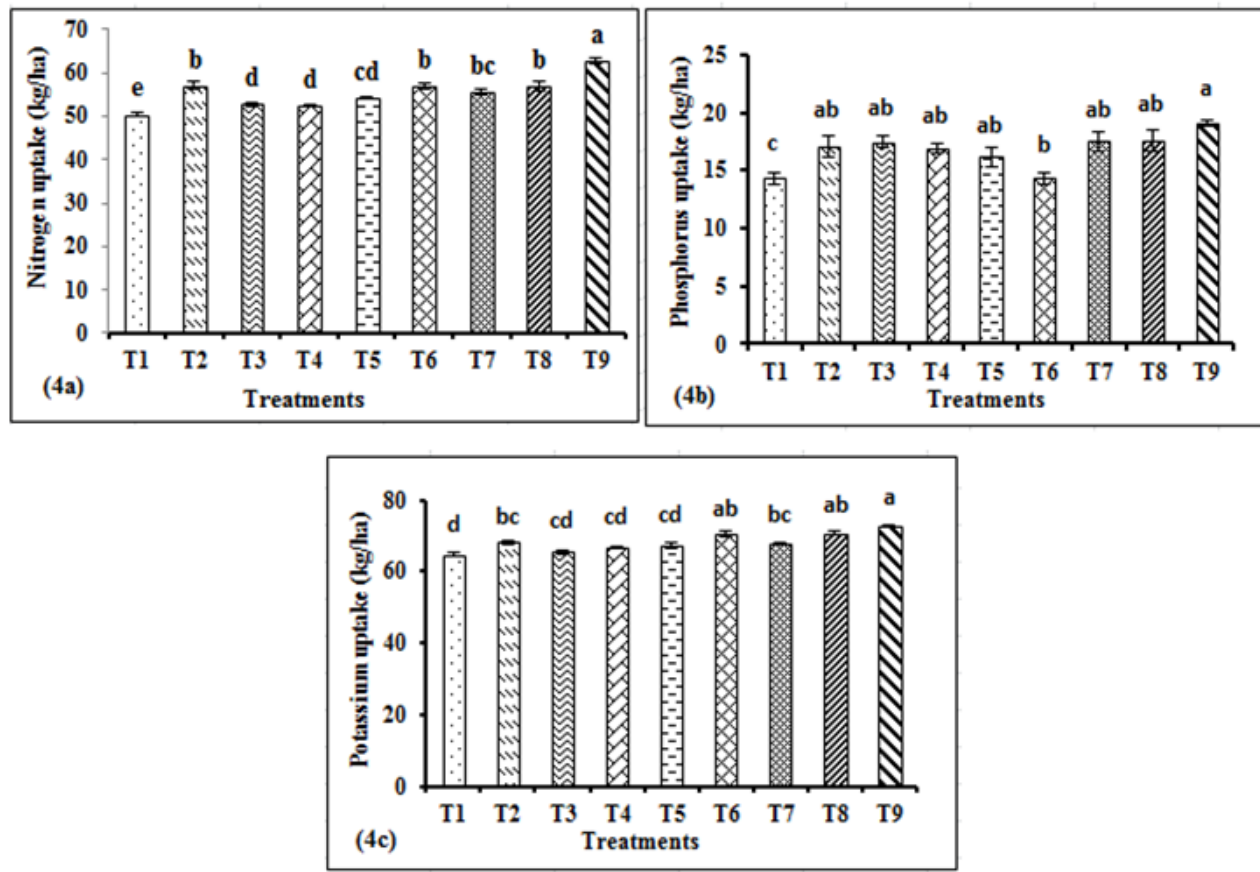

Figure 4 Nutrients uptake (Nitrogen, Phosphorus, and Potassium) of chili as affected by organic manures and NPK Fertilizer.Treatments =T; ( $T$ I; without NPK, GC, C, PM, VC and FYM- control,T2; NI00\%, T3; PI00\%, T4; KI00\%, T5; NPK+GC, T6; NPK+C, T7; NPK+PM,T8; NPK+VC, T9; NPK+FYM). Error bar indicate mean of 4 replication $\pm S E$. Different letters indicate significant difference determined by Student-Newman-Keuls test at $P<0.05$.
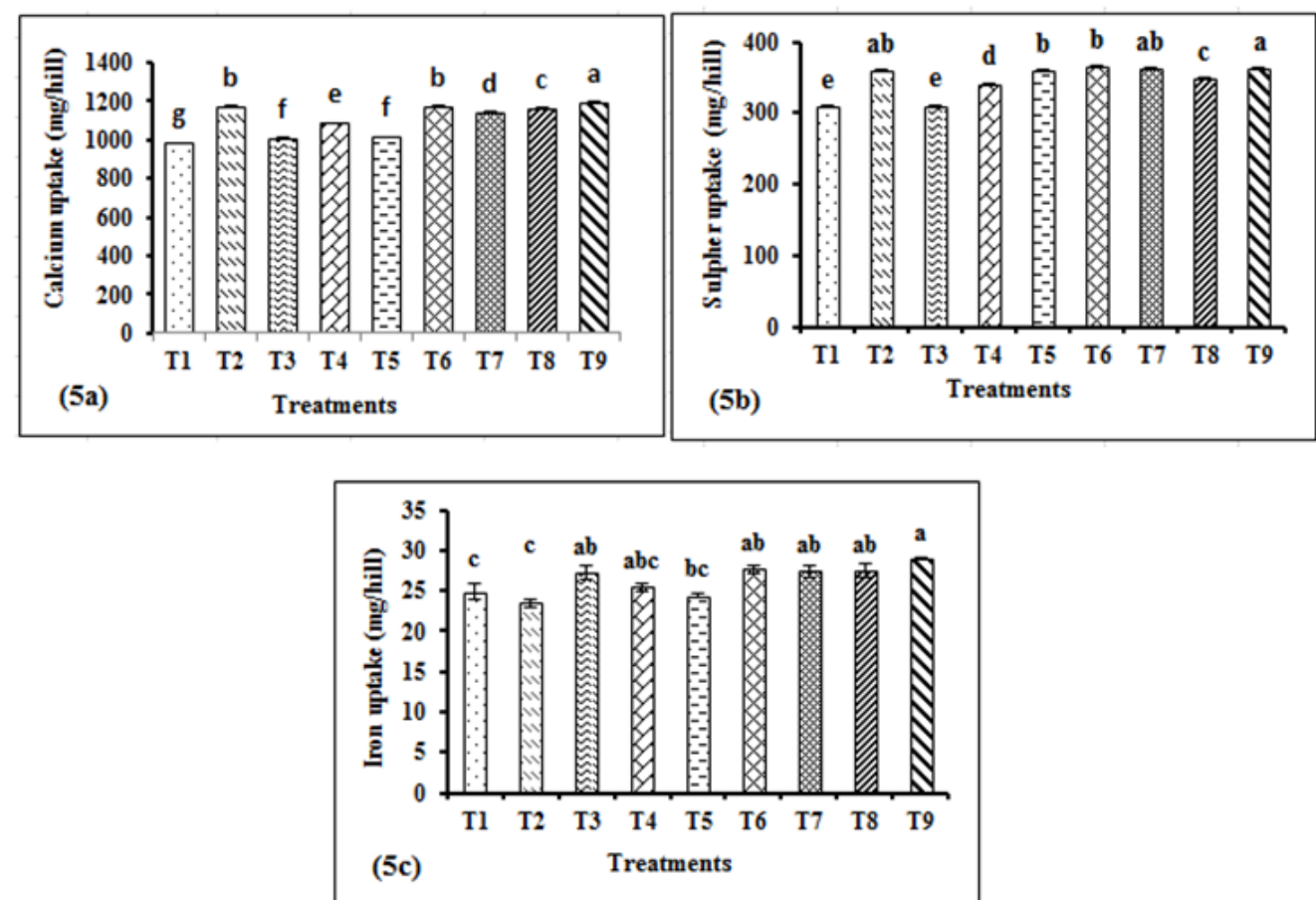

Figure 5 Nutrients uptake (Calcium, Sulpher, and Iron) of chili as affected by organic manures and NPK Fertilizer. Treatments = T; (TI; without NPK, GC, C, PM,VC and FYM- control,T2; NI 00\%,T3; PI 00\%,T4; K I00\%,T5; NPK+GC,T6; NPK+C,T7; NPK+PM,T8; NPK+VC,T9; NPK+FYM). Error bar indicate mean of 4 replication \pm SE. Different letters indicate significant difference determined by Student-Newman-Keuls test at $P<0.05$. 


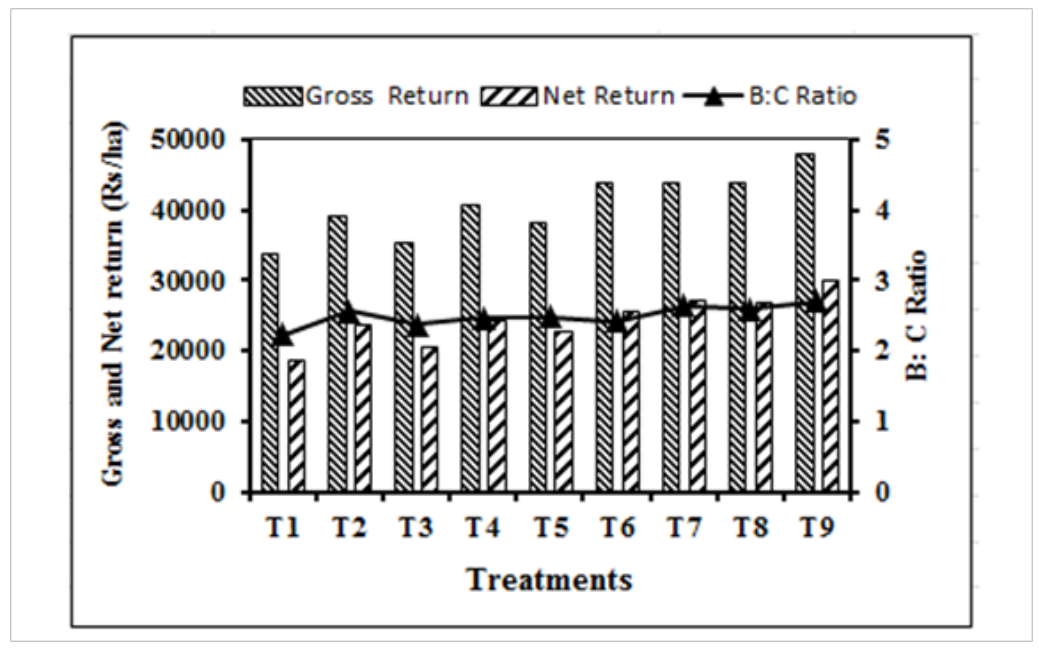

Figure 6 Economics of chilli as affected by organic manures and NPK Fertilizer.Treatments =T; (TI; without NPK, GC, C, PM,VC and FYM- control,T2; NI00\%, T3; PI 00\%,T4; K 100\%,T5; NPK+GC,T6; NPK+C,T7; NPK+PM,T8; NPK+VC,T9; NPK+FYM). Statistical Values are presented in Table 2.

\section{Conclusion}

It can be concluded from the above mentioned outcomes that the application of FYM@8 ton per hectare along with recommended dose of nitrogen, phosphorus and potassium fertilizers proved best treatment for yield increase in chilli, Var. Ghotki as well as improved nutrient uptake. Hence, organic manures along with inorganic fertilizers has positive effect on growth, nutrient uptake, yield and quality of chilli.

\section{Acknowledgments}

None.

\section{Conflict of interest}

Authors declare there is no conflict of interest in publishing the article.

\section{References}

1. Khan MS, Raj SK. First report of molecular detection of an Aster yellows phytoplasma (Candidatus phytoplasma Magdatena Vc. 2003. Salinity and nitrogen rate effects of the growth and yield of chilli pepper plants. $J$ Soil Sci. 2006;67:1781-1789.

2. Udoh JD, Ndoh AB, Asuquo EP, et al. Crop production techniques for the tropics. Concept publications. 2005:261-265.

3. Jilani MS, Burki T, Hussain K, et al. Effect of nitrogen on growth and yield of radish. J Agric Res. 2010;48:219-225.

4. Ahmed NN, Hussain K, Hussain I, et al. An overview of soil fertility and salinity status of Multan district. Ind J Plant Sci. 2004; 3:311-316.

5. Pervez MA, Ayub CM, Saleem BA, et al. Effect of nitrogen levels and spacing on growth and yield of radish (Raphanus sativus L.). Int J Agric Biol. 2004;06:504-506.

6. Mishra P, Dash D. Rejuvenation of bio fertilizer for sustainable agriculture and economic and development. Consilience: J Sustain Dev. 2014;11:41-61

7. Alabi DA. Effects of fertilizer phosphorus and poultry droppings treatments on growth and nutrient components of pepper (Capsicum annuит L.). Afr J Biotechnol. 2006;5:671-677.
8. Pariari A, khan S. Integrated nutrient management of chilli (Capsicum anuum L.) in Gangetic alluvial plains. Journal of Crop and Weed. 2013;9:128-130.

9. FAO. Soil and plant testing as a basis of fertilizer recommendations. Soil Bull. 1980:3812.

10. Gabal MR, Abd-Allah IM, Hass FM, et al. Evaluation of some American tomato cultivars grown for early summer production in Egypt. Ann J Agric Sci.1984;22:487-500.

11. Jackson ML. Soil chemical analysis. Prientice hall of India private limited, New Dehli. 1967:38-82.

12. Bhargava BS, Raghupathi HB. Analysis of plant material for macro and micro nutrients, in: Methods of analysis of soil plant, water and fertilizer. 1993:49-82.

13. Sadsivam S, manikam A. Biochemical method of agricultural sciences. Waily Eastern limited, New Delhi. 1992;178-192.

14. Shashidhara GB. Integrated nutrient management in chilli (Capsicum annum L.) under northern transitional zone of Karnataka. Ph.D. Thesis University of Agriculture Sciences. Dharwad. 2000.

15. Natarajan S. Standardization of nitrogen application chilli grown under semi dry condition. S India Hort. 1990;38:315-318.

16. Chavan PJ, Ismail S, Rudraksha GB, et al. Effect of various nitrogen levels through FYM and urea on yield, uptake of nutrient and ascorbic acid content in chilli (Capsicum annum L.) J Indian soc Soil Sci. 1997;45:833-835.

17. Sutagundi RH. Efeect of mulches and manures on the growth and yield of chilli (Capsicum annum L.) M.Sc. (Agri Thesis, University of Agriculture sciences, Dharwad. 2000.

18. Samsangheile, Kanaujia SP. Integrated nutrient management for quality production of chilli on acid soil. Ann Plant Soil Res. 2014;(16):164-167.

19. Malawadi MN. Effect of secondary and micronutrients on yield and quality of chilli (Capsicum annuum L.). M. Sc. (Agri.) Thesis submitted to UAS. Dharwad, Karnataka, India. 2003.

20. Kattimani S. Response of chilli (Capsicum annuum L.) genotypes to integrated nutrient management. M. Sc. (Agri.) Thesis submitted to UAS. Dharwad, Karnataka, India. 2004. 